\author{
dr Marcin BROL \\ Wydział Nauk Ekonomicznych, Uniwersytet Ekonomiczny we Wrocławiu \\ e-mail: marcin.brol@ue.wroc.pl
}

DOI: $10.15290 /$ ose.2016.01.79.05

\title{
SEKTOR PUBLICZNY A NOWA SFERA PUBLICZNA
}

\begin{abstract}
Streszczenie
Celem artykułu jest próba określenia cech i zakresu nowej sfery publicznej, wskazania jej uczestników, a także implikacji wynikających z jej funkcjonowania. Główna teza opracowania zawiera się w następującym stwierdzeniu: nowa sfera publiczna umożliwia łatwiejsze zaangażowanie społeczne w kwestie publiczne i daje lepsze możliwości agregacji preferencji, co powinno skutkować większą efektywnością działania sektora publicznego. Pojęcie nowej sfery publicznej zostało zaproponowane w opozycji do tradycyjnej - mieszczańskiej, zdefiniowanej przez J. Habermasa. Jej najistotniejszą cecha jest wykorzystanie sieci Internetu, a w szczególności jego asynchronicznych cech do budowania więzi, grup zainteresowań i grup nacisku, wpływających na zakres przedmiotowy sektora publicznego.
\end{abstract}

Słowa kluczowe: sektor publiczny, sfera publiczna

\section{PUBLIC SECTOR AND NEW PUBLIC SPHERE}

\section{Summary}

The aim of this paper is to define the characteristics and scope of the new public sphere, indicate its participants, as well as the implications of its operation. The main thesis can be summarized in the following statement: the new public sphere facilitates involvement in public issues and provides better opportunities for preference aggregation, which should result in greater efficiency of the public sector. The concept of the "new public sphere" has been proposed in opposition to the traditional, bourgeois public sphere, defined by J. Habermas. Its most important attribute is that it uses the Internet, in particular its asynchronous features, to build relationships, interest groups, and pressure groups, influencing the scope of the public sector.

Key words: Public sector, Public sphere

JEL: D7, D70, D71

\section{Wstęp}

Pojęcie sfery publicznej znane jest co najmniej od XVII wieku, kiedy to rozdzielono pojęcia: publiczny i prywatny w kontekście działań oraz wyborów indywidualnych i kolektywnych. W ramach nauk społecznych do dyskursu naukowego to sformułowanie 
wprowadzili: J. Habermas oraz R. Sennett w drugiej połowie XX wieku. Pierwszy z nich zajął się ewolucją sfery publicznej, od mieszczańskiej areny wymiany poglądów do obywatelskiego forum, w którym dyskurs został dostosowany do oczekiwań opinii publicznej i preferencji ,konsumenta” - biernego obserwatora działań publicznych [Habermas, 2007, s. 279-306]. Drugi z badaczy wskazał na zjawisko stopniowego przekształcania postaw wspólnotowych w kierunku postaw egoistycznych i tym samym postawił tezę mówiącą o upadku człowieka publicznego [Sennett, 2009, s. 458-459]. Obserwacje obu wzmiankowanych autorów są w istocie rzeczy podobne - współczesny człowiek nie jest zainteresowany dobrem wspólnym, o ile nie wpływa ono w jakiś sposób na jego prywatne interesy. Naszkicowana przez nich rzeczywistość to: społeczeństwo egoistycznych konsumentów traktujących dyskurs publiczny jako infotainment, czyli rozrywkę opartą na obserwacji gier politycznych i bieżących wydarzeń. Postawy takie prowadzą jednocześnie do alienacji władzy i w konsekwencji większej jej represyjności i despotyczności.

Jednakże wydarzenia ostatnich lat, których katalizatorem i wspólnym mianownikiem była sieć Internetu, zdają się wskazywać na renesans postaw prospołecznościowych i działań kolektywnych. Chodzi tu o oddolne inicjatywy, takie jak: protesty w sprawie przyjęcia umowy ACTA, przeciwstawienie się autorytarnym rząom w krajach Afryki Pó1nocnej i Bliskiego Wschodu, znane jako ,arabska wiosna”, wystąpienia studentów przeciwko płatnym studiom w Chile, a w Polsce wspólnota „,matek pierwszego kwartału” i działania ,miejskich partyzantów”. Wszystkie te inicjatywy powstawały na wirtualnym, internetowym forum publicznym. Można zatem mówić o nowej, wirtualnej czy też sieciowej sferze publicznej, w której forum wymiany jest zlokalizowane w nierzeczywistym, sieciowym otoczeniu.

Istotna kwestia, nieanalizowana do tej pory przez badaczy społecznych, jest postawa instytucji sektora publicznego wobec aktywistów czy też, innymi słowy, aktorów nowej sfery publicznej. Skoro opisane przez J. Habermasa przeobrażenia sfery publicznej prowadziły do zwiększenia dystansu między konsumentem informacji a władza publiczną i wzrostu opresyjności tej drugiej, to oddolne inicjatywy muszą prowadzić do oporu władz i tym samym do antagonizacji aktorów publicznych. Teza ta wydaje się być oczywista, czego dowodem są przytoczone wcześniej przykłady. Zastanawiające jest natomiast, w jaki sposób działania inicjowane przez internetowych aktywistów wpływają na postawy decydentów, w jaki sposób toczy się dyskurs w ramach wirtualnego forum publicznego oraz jakie sa jego skutki. Celem niniejszego opracowania jest zatem próba określenia cech i zakresu nowej sfery publicznej, wskazania jej uczestników, a także implikacji wynikających z jej funkcjonowania. Główną tezę opracowania można sformułować następująco - nowa sfera publiczna umożliwia łatwiejsze zaangażowanie w kwestie publiczne i daje lepsze możliwości agregacji preferencji, co powinno skutkować większą efektywnością działania sektora publicznego. 


\section{Przeobrażenia sfery publicznej i upadek człowieka publicznego}

Ze sferą publiczną jest nierozerwalnie związane słowo 'publiczność'. Tradycyjnie pojęcie to odnosi się do uczestników wydarzeń kulturalnych, takich jak spektakle i koncerty, jednakże jego zastosowanie w odniesieniu do wszelkich zgromadzeń o charakterze publicznym pozwala także zdefiniować mieszczańsko-obywatelską sferę publiczną jako sferę ludzi prywatnych, którzy zbiorowo tworzą publiczność [Habermas, 2007, s. 95]. Z kolei osoby obserwujące i zajmujące określone stanowiska i przedstawiające własne opinie można określić mianem aktorów publicznych [Brol, Czetwertyński, 2013, s. 322].

Wraz z rozwojem cywilizacyjnym dyskurs na forum publicznym zaczął odbywać się nie tylko pomiędzy poszczególnymi aktorami, lecz także przy udziale masowych mediów. Sam fakt oddziaływania mass mediów na publiczność sprawia, że dialog staje się monologiem. Taka forma przekazu nie pozwala publiczności na interakcje, sprawiając, że staje się ona biernym tłumem. Innym zjawiskiem, które nasiliło się w ostatnich dziesięcioleciach, jest komercjalizacja mediów. Jej istotą jest sprzedawanie informacji, zamiast dostarczanie tematów do dyskusji. Spowodowało to osłabienie dyskursu publicznego i zainicjowało proces zwany tabloidyzacją mediów. Pojęcie to oznacza nabywanie cech tabloidu przez prasę codzienną i magazynowa, a następnie przez inne media. Konsekwencją tego procesu jest zmiana priorytetów w konkretnym medium i w konsekwencji wzrost znaczenia rozrywki w obrębie różnych form przekazu. Już czterdzieści lat temu Habermas twierdził, że integracja masowych mediów i reklamy jest jednym z czynników refeudalizacji sfery publicznej [Habermas, 2007, s. 359]. Związane jest to $\mathrm{z}$ faktem, że wymiana informacji między aktorami publicznymi przyjmuje formę reprezentacyjną (charakterystyczną dla okresu feudalnego), gdzie zdecydowana większość obywateli była pasywnymi obserwatorami. Z tego też powodu można zaryzykować twierdzenie, że większość społeczeństwa stanowią nie aktorzy, lecz statyści będący biernymi konsumentami informacji publicznej.

Przekształcenia te istotnie wpłynęły na zjawisko, które R. Sennett nazwał „upadkiem człowieka publicznego", czyli przejściem od społeczeństwa zaangażowanego do zbiorowości tworzonej przez egoistyczne jednostki [Sennett, 2009, s. 457-465]. Rozwijając jego myśl, można zaryzykować stwierdzenie, że mamy do czynienia z atrofią tradycyjnej sfery publicznej, czego wyrazem jest między innymi bezideowość współczesnych organizacji społecznych i partii politycznych, które starają się unikać wszelkich drażliwych tematów społecznych, a także tabloidyzacja i w pewnym sensie prywatyzacja polityki. W ostatnim z wymienionych aspektów chodzi o wywieranie wpływu na władze, podejmujące decyzje publiczne, przede wszystkim przez grupy nacisku związane z przedsiębiorstwami i korporacjami.

Oczywiście atrofia tradycyjnej sfery publicznej nie oznacza, że następuje zanik wszelkich kontaktów społecznych. Należy tu raczej mówić o upadku mieszczańskiej (czy też tradycyjnej) sfery publicznej. Każdy człowiek posiada bowiem potrzebę wyrażania własnych poglądów, stojących zarówno w zgodzie, jak i w opozycji do zdania innych uczestników życia publicznego, a sfera publiczna stanowi środek do realizacji tej skłonno- 
ści. Jeżeli rozważyć hierarchię potrzeb według A. Maslowa, to potrzeby: afiliacji, szacunku i samorealizacji w dużej mierze są wyrażone przez uczestnictwo w dialogu z innymi członkami społeczeństwa. W ujęciu węższym będzie to rodzina, a w ujęciu szerszym właśnie publiczność. Stąd też sfera publiczna sui generis nie zanika, lecz traci swoją pierwotną formę.

Konsekwencją atrofii tradycyjnej sfery publicznej jest korporatyzacja podmiotów sektora publicznego. Przejawem tego zjawiska jest komercjalizacja podmiotów publicznych świadczących usługi publiczne oraz przeniesienie do nich technik zarządzania stosowanych w przedsiębiorstwach prywatnych. Zresztą formalne przekształcenie zakładów budżetowych w spółki prawa handlowego ustawodawca nakazał na mocy Ustawy o finansach public znych. W samym tylko 2010 roku w polskich samorządach w spółki komunalne przekształcono 90 zakładów budżetowych, utworzono 159 nowych spółek z o.o. oraz 90 spółek akcyjnych [Jerzmanowski, 2012]. Z cała pewnością zaletą tego rozwiązania jest większa racjonalność gospodarowania i większa zdolność kredytowa spółek, a z punktu widzenia jednostek publicznych brak odpowiedzialności za ich zobowiązania. Jednakże doświadczenia ostatnich lat wydają się także wskazywać negatywne, w szczególności z perspektywy obywatela, konsekwencje takich przekształceń. Chodzi tu mianowicie o możliwość świadczenia przez tego typu spółki usług o charakterze komercyjnym, a co za tym idzie, ograniczenie działalności na rzecz społeczeństwa.

Według danych NIK, na Dolnym Śląsku w pięciu skontrolowanych w 2009 roku miastach spółki komunalne podejmowały działalność komercyjna, w wyniku której pojawiało się ryzyko praktyk monopolistycznych, a także nieuczciwej konkurencji. W Polkowicach była w ten sposób prowadzona działalność hotelowo-restauracyjna, we Wrocławiu miasto było właścicielem zawodowych klubów sportowych, a w Legnicy telewizji lokalnej i giełdy hurtowej. W konkluzji do przeprowadzonej kontroli, urzędnicy NIK stwierdzili, że (...) działalność ta nie tylko uylk raczała poza sfere uìyteczności publicznej, ale zdaniem NIK nie by la zwiqzana z realizacja ustawonych zadan tych gmin [NIK, 2010]. Co prawda, późniejsze zmiany Ustawy o gospodarce komunalnej dopuściły zaangażowanie w sport zawodowy, lecz w momencie przeprowadzenia kontroli działalność taka była niezgodna $z$ prawem.

Jednakże wątpliwości co do zasadności zaangażowania podmiotów publicznych w działalność komercyjną nie świadczą o atrofii sfery publicznej. Natomiast dowodzi tego sposób ich działania. Ponieważ są to spółki prawa handlowego, częstokroć tłumacząc się tajemnicą handlowa, nie informują opinii społecznej o przedmiocie swojej działalności, zawartych kontraktach ani wynikach finansowych. We Wrocławiu wątpliwości wzbudziło udzielenie pożyczki przez Miejskie Przedsiębiorstwo Wodociagów i Kanalizacji w wysokości 4 mln zł innej miejskiej spółce WKS „Śląsk Wrocław” S.A. Miejskie Przedsiębiorstwo Wodociagów i Kanalizacji odmówiło odpowiedzi na pytania o zasady, na jakich udzieliło wsparcia, oraz sposób spłaty. Tymczasem zarząd klubu piłkarskiego oświadczyl, że ujanmienie umony mogtoby mieć negatywny wplyw na sytuacje spótki i jej pozycje konkurencyjna [Kokoszkiewicz, 2013]. Wojewódzki Sąd Administracyjny we Wrocławiu nakazał jednak ujawnienie umowy, wskazując na fakt, że obywatele maja prawo do nadzorowania działalności spółek z udziałem miasta. 
W warunkach osłabienia społecznego zainteresowania sprawami publicznymi, decydenci zdają się wykazywać pokusę do ukrywania informacji związanych z gospodarowaniem mieniem publicznym, a tworzone publiczne spółki zdają się traktować jako przedsiębiorstwa pozwalające na realizację własnych celów biznesowych i politycznych. Trudno jednoznacznie potwierdzić to przypuszczenie, a ocena efektywności działalności tego typu podmiotów nie jest celem niniejszego artykułu. Zjawisko to wydaje się jednak wpisywać, we wspomnianą już wcześniej, refeudalizację sfery publicznej, wzmiankowanej przez Habermasa.

\section{Sieciowa sfera publiczna}

Upowszechnienie sieci Internetu umożliwiło swobodny przepływ informacji pomiędzy wszystkimi aktorami publicznymi (także tymi biernymi), jak również tworzenie nowych więzi społecznych. Według Castellsa, Internet jest dla społeczeństwa sieciowego tym, czym była sieć energetyczna dla społeczeństwa industrialnego [Castells, 2003, s. 11]. W ujęciu ekonomicznym oznacza to spadek kosztów uczestnictwa w życiu publicznym. Dzięki cyfryzacji i Internetowi koszty krańcowe twórczości internetowych autorów są niemalże zerowe. W konsekwencji koszty całkowite ograniczają się do kosztów stałych, ponieważ koszty zmienne jako suma kosztów krańcowych również są bliskie zeru. Podobna zależność dotyczy kosztów dostępu do treści on-line [Brol, Czetwertyński, 2013, s. 325].

Podstawową cechą Internetu jest asynchroniczność zachodzących w nim interakcji [Levinson, 2006, s. 224]. Chodzi w tym przypadku o brak ograniczeń przestrzennych i czasowych. Osoba uczestnicząca w wymianie poglądów nie musi być fizycznie obecna na forum publicum. Może także swoją wypowiedź umieścić w sieci w dowolnym czasie. Daje to aktorom publicznym możliwość interakcji niezależnie od miejsca zamieszkania i pory dnia, w której sa on-line. Nie te cechy warunkuja jednak powstanie nowej sfery publicznej. Sa one bowiem jedynie pewnym usprawnieniem w ramach dyskursu publicznego. Najważniejsza jest asynchroniczność statusu społecznego, a więc uniezależnienie od zajmowanej pozycji społecznej i statusu materialnego. W sieci każdy głos ma tę samą wagę, a o jego sile decyduje treść wypowiedzi.

Areną nowej sfery publicznej są wszystkie wirtualne przestrzenie, spełniające wymienione powyżej kryteria, a więc: fora internetowe, blogi (w tym fotoblogi i wideoblogi) oraz media społecznościowe. Ich istota jest generowanie i udostępnianie treści przez ich użytkowników [Kaplan, Haenlein, 2010, s. 61]. Z tego względu przedmiotem zainteresowania nowych aktorów publicznych mogą być zarówno sprawy obejmujące ogół społeczeństwa związane z: polityka, wyborami, sytuacją międzynarodowa, ekonomią jak i zagadnienia dotyczące wąskich grup tematycznych: kolekcjonerów, alpinistów, narciarzy, turystów, piłkarzy itp. Media społecznościowe tym różnią się od mass mediów, że przepływające przez nie treści nie mają charakteru masowego, lecz indywidualny. W efekcie występuje duża dywersyfikacja poglądów i celów aktorów publicznych. Castells zauważa, że różnorodność treści Internetu w dużej mierze jest związana z faktem, że ruchy społeczne spoza głównego nurtu dopiero tu znalazły miejsce wyrazu [Castells, 
2003, s. 65-66]. Poszukiwanie własnej tożsamości w sieci czyni informacje przepływające przez Internet zróżnicowanymi.

Podsumowując rozważania nad rolą mediów społecznościowych w sieciowej sferze publicznej, należy stwierdzić, że są one transmiterem aktywności aktorów publicznych. Jeżeli sama publiczność jest nośnikiem opinii publicznej, to media społecznościowe są jej emanacja. W stosunku do tradycyjnej aktywności aktorów publicznych, w nowej sferze publicznej zmianie uległa skala ich oddziaływania. Dotychczasowe fora publiczne, takie jak: trybuny, wiece i manifestacje były zaadresowane do nielicznego grona odbiorców. Wpisy na blogach potencjalnie mają miliardy odbiorców - tylu ilu jest internautów. Choć z pewnością większość z nich nie trafi do szerszej publiczności, to w szczególnych przypadkach może wywołać daleko idące reperkusje w postaci: zmian w alokacji środków publicznych, presji politycznej, demonstracji lub nawet konfliktów zbrojnych. Transformacja sfery publicznej z tradycyjnej w sieciową nie mogłaby się dokonać bez mediów społecznościowych. Są one zarazem konsekwencją i przyczyną nowych relacji w sieciowej sferze publicznej.

\section{Aktorzy publiczni w nowej sferze publicznej}

Problem, jaki dotyczy sektora publicznego w zmieniającej się sferze publicznej, ma z jednej strony wymiar komunikacyjny, a z drugiej strony systemowy. Pierwszy z problemów wiąze się z brakiem umiejętności wykorzystania nowych mediów w procesie agregacji preferencji. Natomiast drugi ma o wiele poważniejsze skutki i wynika bezpośrednio z procesu refeudalizacji sfery publicznej.

W wyniku refeudalizacji agregacja preferencji w sektorze publicznym ogranicza się do cyklicznych kampanii wyborczych, uzupełnianych sondażowymi badaniami opinii publicznej. Narzędziem marginalnie stosowanym w tym zakresie są również konsultacje społeczne, które nie spełniają swojej funkcji, ze względu na nikłe zainteresowanie nimi społeczeństwa oraz brak pewności co do implementacji ich wyników. W Polsce władze publiczne zdają się nie być zainteresowane zmianą tego stanu rzeczy z uwagi na upolitycznienie struktur administracyjnych, zarówno na szczeblu centralnym, jak i samorządowym. Świadczą o tym liczne przypadki konfliktów pomiędzy osobami odpowiedzialnymi za dostarczanie usług publicznych a lokalnymi aktywistami.

Z konfliktem na wiele większą skalę mamy do czynienia w państwach, w których portale społecznościowe de facto stanowią jedyny kanał, za pośrednictwem którego aktorzy publiczni moga prezentować swoje poglądy. Chodzi tu o kraje niedemokratyczne lub autorytarne o ograniczonych swobodach obywatelskich, takie jak: Egipt, Tunezja czy Turcja. We wszystkich z nich dochodziło w ostatnich latach do protestów albo obywatelskich przewrotów, skutkujących niepokojami społecznymi bądź też obaleniem dotychczasowych władz. Wydarzenia takie miały miejsce w Afryce Północnej i zyskały miano „arabskiej wiosny”. Za początek okresu niepokojów społecznych w krajach arabskich uznaje się wydarzenia, które miały miejsce 17 grudnia 2010 roku w Tunezji. Doszło tam do samospalenia 23-letniego sprzedawcy owoców Moha- 
meda Bouazizi przed siedzibą lokalnego gubernatora. Dokonał tego w proteście przeciwko niesprawiedliwemu traktowaniu przez władze, po tym jak strażnicy miejscy pobili go i zarekwirowali wózek, z którego sprzedawał owoce [Sadian, 2012, s. 25]. Konsekwencją jego czynu był wybuch rewolty społecznej w Tunezji, a następnie w 16 kolejnych krajach Afryki Północnej i Bliskiego Wschodu [Sadian, 2012, s. 25].

Charakterystycznym zjawiskiem towarzyszącym ,arabskiej wiośnie” był nieskrępowany przepływ informacji za pośrednictwem Internetu i portali społecznościowych, co dało organizatorom możliwość: planowania, organizowania i koordynowania działań. Przede wszystkim skutkowało upublicznieniem informacji kompromitujących rządzących, dotyczących korupcji i defraudacji środków publicznych. Przewrót w Tunezji jest także nazywany „rewolucją Wikileaks”, od nazwy portalu internetowego publikującego „przecieki” z oficjalnej korespondencji dyplomatycznej, obnażające korupcję i wystawny styl życia prominentów reżimu [Stefanicki, 2011].

Nieco inne źródła i przebieg miały protesty w Turcji. Fala demonstracji rozpoczęła się 30 maja 2013 roku w Stambule na placu Taksim. Bezpośrednim celem pierwszej z serii demonstracji było zapobieżenie przebudowie jednego z ważniejszych placów w mieście oraz likwidacji miejskiego parku Gezi [Tysiqce Turkón znón protestuje..., 2013]. Informacje o wydarzeniu oraz reakcja na nie ze strony władz były publikowane na bieżąco za pomoca portali społecznościowych, takich jak: Twitter, Facebook i Youtube. Brutalność i bezwzględność policji oraz lekceważenie postulatów protestujących przez władze miejskie i centralne zostały opisane i udokumentowane (sfilmowane i sfotografowane) przez aktorów publicznych, publikujących w Internecie. Wywołało to powszechne oburzenie znacznej części opinii publicznej i dalszą eskalację przemocy. Na skutek kilkumiesięcznych starć zginęło 5 osób, a rannych zostało ponad 8000 [Amnesty International, 2014]. Władze tureckie uznały, że najlepszym sposobem na uspokojenie sytuacji nie będzie zmiana planów i negocjacje z protestującymi, lecz odcięcie ich od mediów społecznościowych. W pierwszej kolejności zablokowano więc dostęp z terenu Turcji do Twittera, a po tygodniu także do Youtube [Tydzień po blokadzie..., 2014]. W obliczu protestów podobne działania podjęły wcześniej władze w Egipcie, które zdecydowały się całkowicie odciąć kraj od dostępu do Internetu [Stefanicki, 2011].

Cechą charakterystyczną tureckich protestów była szybka eskalacja niepokojów. Pierwotnie protest dotyczył bowiem lokalnych problemów związanych z zagospodarowaniem terenów miejskich. Jednakże upublicznienie za pomocą Internetu wszystkich informacji związanych z przebiegiem demonstracji spowodowało lawinę poparcia dla demonstrantów. Podobne wydarzenia miały miejsce w Brazylii, gdzie przedmiotem sporu okazała się 20-procentowa podwyżka cen biletów komunikacji miejskiej [Tysiqce Turkón znów protestuje..., 2013]. Taka eskalacja protestów ilustruje zjawisko opisywane w literaturze przedmiotu jako efekty zewnętrzne sieci [Shapiro, Varian, 2007, s. 199-200]. Konsekwencją odrzucenia postulatów aktywistów przez władze publiczne zarówno w Turcji, jak i Brazylii był wzrost niezadowolenia społecznego i przyłączenie się do protestów także innych grup walczących o swoje interesy.

W przypadku występowania efektów zewnętrznych sieci: (...) uisyteczৃość danej osoby z. konsumpcii pewnego dobra zalešy od licz̧by innych osób konsumujacych to dobro [Varian, 2005, s. 630]. Innymi słowy, liczba osób tworzących sieć wpływa na jej użyteczność dla 
poszczególnych uczestników. Istnieje pewien punkt masy krytycznej, po przekroczeniu którego koszty uczestnictwa w sieci są mniejsze niż korzyści płynące z uczestnictwa w niej. Powyżej niego, wzrost użyteczności jest więcej niż proporcjonalny względem wzrostu kosztu uczestnictwa. Wyrazem tego jest sprzężenie zwrotne, za sprawa którego silni stają się silniejsi, a słabi słabsi [Shapiro, Varian, 2007, s. 191-195]. Sieci, które osiagnęły swój punkt krytyczny, przyciągają coraz szerszą liczbę uczestników, powodując ich odpływ z sieci konkurencyjnych. Oznacza to, że część działań aktorów publicznych znajdzie aprobatę innych aktorów, a część pozostanie bez echa. Sytuacja taka miała również miejsce w Polsce w odniesieniu do protestów przeciwko ratyfikacji umowy ACTA.

\section{Sektor publiczny w nowej sferze publicznej}

W Polsce aktywność aktorów publicznych, działających w ramach portali społecznościowych, związana jest zazwyczaj z realizacją przedsięwzięć lokalnych, chociaż zdarzają się także akcje prowadzone na większą skalę. Pierwszym ogólnokrajowym przypadkiem, w który zaangażowali się aktorzy publiczni działający w sieciowej sferze publicznej, był sprzeciw wobec ratyfikacji międzynarodowej umowy ACTA dotyczącej ochrony własności intelektualnej.

W tym przypadku również wystąpił, wspomniany wcześniej, efekt sieci. Organizacja oraz koordynacja protestów odbywała się poprzez portale społecznościowe, w głównej mierze Facebooka i Twittera. Ani w czasie protestów, ani bezpośrednio po ich zakończeniu nie wyłoniono konkretnego lidera (lub grupy liderów), który sterowałby akcją. Świadczy to o tym, że grupa nacisku stworzona w tym konkretnym przypadku miała charakter sieci partnerskiej, czyli takiej, w której wszyscy uczestnicy są równi, niezależnie od: statusu społecznego, ograniczeń przestrzennych lub czasowych. Czynnikiem spajającym sieć stał się wspólny cel - sprzeciw.

Podobny przebieg miała inna akcja, tzw. matek pierwszego kwartału. Dotyczyła ona zrównania prawa wszystkich matek, które urodziły w 2013 roku, do dłuższego urlopu macierzyńskiego. Rząd planował bowiem, że nowe zasady regulujące długość tego urlopu będą obowiązywać nie od początku roku, lecz od 17 marca. Grupa uaktywniła się na portalu społecznościowym Facebook, a następnie zyskała rozgłos także w tradycyjnych mediach. W przeciwieństwie do ruchu przeciwko ACTA, aktorzy publiczni nie uciekali się do protestów ulicznych, a ich postulaty zostały ostatecznie spełnione (szacuje się, że decyzja ta wymagała zabezpieczenia w budżecie około $500 \mathrm{mln}$ zł), (Piechowiak, 2013].

Mechanizm wpływu na kształt decyzji publicznych, w tym decyzji alokacyjnych za pomocą mediów społecznościowych, staje się zatem jedną z metod działania grup nacisku. Z tą jednak różnicą w stosunku do tradycyjnych lobbystów, że grupy interesów działające w sferze wirtualnej wykorzystują efekt sieci oraz asynchroniczność interakcji w celu zwiększania swojej siły oddziaływania. Wraz ze względną anonimowościa doprowadziło to do rozkwitu więzi społecznych pomiędzy osobami, które w trady- 
cyjnej sferze publicznej nie byłyby w stanie ich wytworzyć. Ułatwiły to media społeczne, a głównie portale społecznościowe, będące platformami wymiany informacji i skupiające osoby o podobnych przekonaniach.

Akceptacja zmian, jakie dokonują się w sferze publicznej, przez decydentów sektora publicznego może po pierwsze ułatwić agregację preferencji, a po drugie przyczynić się do zwiększenia aktywności obywatelskiej. Należy także w tym miejscu wspomnieć o niskich kosztach takiego rozwiązania, ponieważ dialog pomiędzy aktorami publicznymi (z jednej strony aktywistami internetowymi, a z drugiej przedstawicielami władz publicznych) odbywa się za pomocą istniejaccych platform wymiany pogląóow - mediów społecznościowych i nie wymaga prowadzenia kosztownych badań opinii i konsultacji społecznych.

Niektóre samorządy w coraz większym stopniu zdają się akceptować rolę nowych aktorów publicznych i skłonne są dopuścić ich do współudziału w decyzjach alokacyjnych. Mowa tu przede wszystkim o budżetach obywatelskich. Przykładowo, we Wrocławiu, już w pierwszym roku stosowania tego narzędzia, zgłoszono ponad 240 projektów inwestycji, a w kolejnym już 481 [Wroctawski Budǐet Obywatelski], co świadczy o znaczącym wzroście zainteresowania mieszkańców sprawami dotyczącymi ich bezpośrednio. Jednak z dwóch powodów projekty budżetów obywatelskich w pełni nie wpisują się w nową sferę publiczną. Po pierwsze, ze względu na rygory natury technicznej (gotowe formularze zgłoszeń, sztywne terminy, formalne złożenie podpisów pod projektem i wskazanie liderów odpowiadających za projekt) nie została zachowana asynchroniczność interakcji. Po drugie, mimo możliwości dialogu za pomocą sieci Internetu, cała akcja zgłaszania propozycji inwestycyjnych i głosowania nad nimi nie jest prowadzona w sposób spontaniczny, co może wpływać na preferencje głosujacych. Mogą bowiem oni przyjmować różne strategie zachowania, przejawiające się np. tworzeniem porozumień i koalicji między osiedlami lub głosowaniem nie za danym projektem, lecz przeciw innemu.

Niestety, nadal istnieje opór przed nadmiernym, zdaniem władz publicznych, ingerowaniem aktywistów w sprawy publiczne. Efektem tego jest istnienie grup społecznych działających w opozycji do instytucji publicznych. Za przykład mogą tu posłużyć działania tzw. miejskich partyzantów. Pierwotnie ich działalność została zainicjowana w USA, gdzie za pomoca portali społecznościowych organizowano akcje sadzenia kwiatów i warzyw na miejskich: placach, skwerach i klombach. W Polsce działalność taka jest prowadzona w kilku miastach. W Gorzowie Wielkopolskim akcję tę od kilku lat koordynuje stowarzyszenie „Sztuka miasta”. Zazwyczaj partyzanci organizują się dzięki mediom społecznościowym i działają w nocy. Efekty ich działania, wbrew temu co mogłoby się wydawać, nie cieszą się przychylnością władz miasta, ponieważ więcej kwiatów i drzew oznacza wyższe koszty utrzymania zieleni. Stąd też efekty ich pracy są zazwyczaj niszczone podczas kolejnego koszenia trawników [Drzewiecka, 2014].

Innym przykładem działania partyzantów jest niszczenie nielegalnie powieszonych reklam. Zdaniem aktywistów, reklamy zaburzają estetykę miasta, a przestrzeń publiczną należy traktować jako dobro wspólne, które powinno być chronione. W Poznaniu „antyreklamowi partyzanci” zniszczyli około 900 reklam, a w Krakowie ich działania wymusiły na miejskich radnych uznanie Starego Miasta za park kulturowy, na terenie 
którego nie wolno umieszczać reklam [Łukaszewski, 2013]. Nieco inny przebieg mają działania partyzantów walczących z reklamami we Wrocławiu. Zamalowują oni tam wszystkie szpecące przestrzeń banery reklamowe, nawet te powieszone legalnie. Uznali oni bowiem, że miasto, które jako Europejska Stolica Kultury reklamuje się hasłem „przestrzenie dla piękna”, powinno określić reguły funkcjonowania nośników reklamowych w miejskiej przestrzeni [Nogaj, 2014]. Brak odpowiednich regulacji wynika najczęściej z nikłego zainteresowania samorządów kwestiami estetyki przestrzeni, a także braku środków na kontrole i egzekwowanie ewentualnych zakazów i wytycznych.

\section{Podsumowanie}

Uświadomienie zarówno władzom lokalnym, jak i centralnym potencjału, jaki maja portale społecznościowe w zakresie pobudzania aktywności społeczności lokalnych oraz agregacji preferencji, skutkować może większą efektywnością usług publicznych i niższymi kosztami funkcjonowania sektora publicznego. Zaangażowanie aktywistów może również wskazywać pożądane ze społecznego punktu widzenia rozwiązania legislacyjne. Działając w zgodzie z oddolnymi ruchami animowanymi przez aktorów nowej, sieciowej sfery publicznej, dysponujący środkami publicznymi zyskują dodatkowe narzędzie zarządzania sektorem publicznym.

Jak wskazuja przytoczone w artykule przykłady, inicjatywy lekceważone lub odrzucane przez decydentów (takie jak ruchy przeciwko ACTA czy miejska partyzantka) z czasem gromadzą coraz większą liczbę osób w nie zaangażowanych. Działające na zasadzie śnieżnej kuli, dodatnie efekty sieci będą potęgować niezadowolenie społeczne i w konsekwencji moga doprowadzić do siłowego wymuszenia postulowanych zmian lub działań. Z punktu widzenia rządzących konsekwencją może być nie tylko przegranie sporu, w który zaangażowali swój autorytet, ale także wzrost ogólnego poziomu niezadowolenia społecznego.

Łatwiejszym i tańszym rozwiązaniem dla władz publicznych jest aktywny współudział nowej sfery publicznej w roli aktorów. W ten sposób zyskuje się szybszy przepływ informacji skutkujący większymi możliwościami odczytania nastrojów społecznych, jak również możliwość ich kształtowania. Jednak przedstawiciele władz działający na tym polu nie powinni ograniczać się do tworzenia „martwych” kont na portalach społecznościowych, które byłyby jedynie ich wyborczą wizytówka, lecz faktycznie uczestniczyć w prowadzonym dialogu. Jedna z charakterystycznych cech internetowych aktywistów jest bowiem zdolność do wychwytywania wszelkich przekłamań i sztuczności.

\section{Literatura}

AddingInjustice to Injury, 2014, Amnesty International, London.

Brol M., Czetwertyński S., 2013, Ksžtaltowanie preferencji podmiotów rynkowych w dobie cyfryzacii, „Ekonomia i Prawo”, t. XII, nr 2.

Castells M., 2003, Galaktyka Internetu: Refleksje nad Internetem, biznesem i spoleczeństwem, Dom Wydawniczy Rebis, Poznań. 
Drzewiecka A., 2014, Ludzie kwiaty, çyli miejscy partyzanci, http://www.mmgorzow.pl/ artykul/ludzie-kwiaty-czyli-miejscy-partyzanci (data wejścia: 21.03.2014).

Tydzień po blokadzie Twittera Turcja blokuje YouTube'a, 2014, „Gazeta Wyborcza”, http://wyborcza.pl/1,75477,15699980,Tydzien_po_blokadzie_Twittera_Turcja_ blokuje_YouTube_a_.html, data wejścia: 27.03.2014].

Habermas J., 2007, Strukturalne przeobrażenia sfery publicznej, Wydawnictwo Naukowe PWN, Warszawa.

Informacja o wynikach kontroli funk.jonowania wybranych spótek z udziatem samorzqdu gminnego na terenie Dolnego Ślaska, 2010, Najwyższa Izba Kontroli, Delegatura we Wrocławiu, Wrocław.

Jerzmanowski Z., 2012, Zalety spółek komunalnych, „Wspólnota”, nr 25/26.

Kaplan A. M., Haenlein M., 2010, Users of the world, unite! The challenges and opportunities of Social Media, „Business Horizons”, vol. 53.

Kokoszkiewicz M., 2013, Dlaczego MPWiK musi ujawnić umowe ze Ślaskiem W rocław, http://wroclaw.gazeta.pl/wroclaw/1,35771,15112787,Dlaczego_MPWiK_musi _ujawnic_umowe_ze_Slaskiem_Wroclaw.html\#ixzz38woPI83Z (data wejścia: 27.03.2014).

Levinson P., 2006, Miekkeie ostrze, cayli historia i prayszłośc rewolucji informacyjnej, Warszawskie Wydawnictwo Literackie MUZA SA, Warszawa.

Łukaszewski J., 2014, Z nożyczkami na nielegalne reklamy. Miejscy partyzanci z sekatorami, http://poznan.gazeta.pl/poznan/1,36037,14212746,Z_nozyczkami_na_nielegalne _reklamy_Miejscy_partyzanci.html\#ixzz38wtSVbSs (data wejścia: 28.03.2014).

Nogaj M., 2014, Partyzanci pod ostonq nocy walczq z. reklamami, http://wroclaw.gazeta.pl/wroclaw/1,35771,16266779,Partyzanci_pod_oslona_nocy_walcza_z_rekla mami.html (data wejścia: 4.07.2014).

Piechowiak L., 2013, O co tak naprawde walczq „matki pierwszego kwartału”?, http:/ /www.bankier.pl/ wiadomosc/O-co-tak-naprawde-walcza-matki-pierwszegokwartalu-2738692.html (data wejścia: 15.04.2014).

Sadian J. C., 2012, The Arab Spring - One yearlater, „The CenSEI Report”, vol. 2, no. 6. Sennett R., 2009, Upadek człowieka publicznego, Warszawskie Wydawnictwo Literackie MUZA SA, Warszawa.

Shapiro C., Varian H. R., 2007, Potega informacji. Strategiczny przewodnik po gospodarce cyfrowej, Wydawnictwo HELION, Gliwice.

Stefanicki R., 2011, Lastminute prezydenta Ben Alego, http://wyborcza.pl/1,768 42,8987389,Last_minute_prezydenta_Ben_Alego.html (data wejścia: 20.04.2014).

Tysiace Turków znów protestuje przeciwko Erdoganowi, 2013, „Rzeczpospolita”, http:/ /www.rp.pl/artykul/1022520.html (data wejścia: 20.04.2014).

Varian H. R., 2005, Mikroekonomia. Kurs średni - ujecie nowoczesne, Wydawnictwo Naukowe PWN, Warszawa.

Wrocławski Budizet Obywatelski, Wroclaw.pl, http://www.wroclaw.pl/wroclawski-budzetobywatelski (data wejścia: 09.05.2014). 